\title{
The Development of Two Stay-Two Stray Cooperative Learning Instrument on Respiratory System to Improve Scientific Literacy Skills
}

\author{
Sylvani Kumala Ulinnuha', Muslimin Ibrahim², Utiyah Azizah ${ }^{3}$ \\ 1,2,3Pascasarjana Universitas Negeri Surabaya, Surabaya, Indonesia
}

\begin{tabular}{|c|c|}
\hline (A) Check for updates open access cc) (i) (2) & DOI : https://doi.org/10.46245/ijorer.v2i5.139 \\
\hline Sections Info & ABSTRACT \\
\hline Article history: & Science literacy is an ability to understand, communicate science through oral \\
\hline Submitted: July 21, 2021 & or written, apply and analyze the current scientific issues in society. This \\
\hline Final Revised: August 13, 2021 & study aims to produce a valid, practical, and effective learning tool, and has \\
\hline $\begin{array}{l}\text { Accepted: September 15, } 2021 \\
\text { Published: September 30, } 2021\end{array}$ & been carried out using the 4D (Define, Design, Development, and \\
\hline Keywords: & Disseminate) method; however, the Disseminate one wasn't carried out. The \\
\hline Scientific Literacy & examination was limited in using one group pretest-post test design. The \\
\hline Respiratory System & study was conducted within two meetings with 16 who were doing online \\
\hline Two Stay-Two Stray & learning. The data retrieval used a validated instrument. RPP tools with very \\
\hline 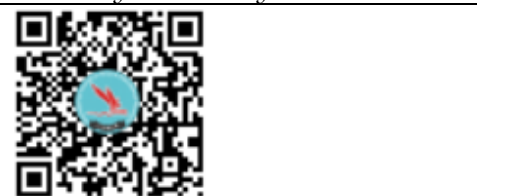 & $\begin{array}{l}\text { decent results, LKPD tools (Student Worksheets) with very decent results, and } \\
\text { test kits (Pre-test and post-test) with very decent results. As the result, the } \\
\text { learning method shows to be very decent, effective, and practical, while the } \\
\text { items of the method used are included in the sensitive category } \geq 0.30 \text {. }\end{array}$ \\
\hline
\end{tabular}

\section{INTRODUCTION}

Herdiani (2013) states that according to PISA (Program for International Student Assessment), scientific literacy is an ability to use a scientific skill, such as identifying questions and drawing conclusions based on the evidence. The skill is used to make decisions and changes related to nature through human activities. Nurjannah et al (2017) also has a similar definition of scientific literacy, in which scientific literacy is someone's ability to solve and analyze current scientific issues in society scientifically. This can be interpreted that someone who has scientific literacy skills is someone who is able to apply scientific concepts to various natural phenomena that occur in everyday life. In this study, the discussed science literacy is an ability to understand, communicate science through oral or written, apply and analyze the current scientific issues in society. The low level of scientific literacy causes students to be less responsive to developments and problems exist especially the one that related to natural phenomena, local advantages, and problems in the surrounding environment.

Through an interview with one of the Biology teachers at Senior High School 14 Surabaya, the school only implemented 15 minutes of reading as a literacy activity before the teaching and learning activity, according to the Gerakan Literasi Sekolah (GLS) or school literacy movement on habituation stage. Science literacy activities in school have not been included in learning achievement. The implementation of GLS has been going well, even though it is still in the habituation stage; before the teaching and learning activity starts, students will read books other than school subject books for 15 minutes. In this activity, the teachers act as role models. There is no assessment in this activity. 
The Development of Two Stay-Two Stray Cooperative Learning Instrument on Respiratory System to Improve Scientific Literacy Skills

On the implementation of scientific literacy in the school's teaching and learning activity, it is necessary to have an instrument as a reference in carrying out similar activities on the appropriate material. The alternative to developing this instrument was chosen since it provides an overview of learning and steps by the needs in certain learning methods, and its validity has been tested. According to Sukristanto et al (2019), teachers are required to master a variety of learning methods that are useful for students to have a high absorption of new patterns and methods.

Therefore, it is necessary to develop a strategy to improve scientific literacy (Nofiana and Julianto, 2018). This literacy movement is intriguing to be applied to subjects since there is a need for a method to solve students' problems in achieving a successful teaching and learning process. Students' scientific literacy is not only enhanced through their learning motivation, but teachers also need to consider related learning methods and make students actively involved during the teaching and learning process (Septimarmisa et al., 2018).

One of the methods that can support this literacy movement is the Two Stay-Two Stray (TS-TS) method. The Two Stay-Two Stray method can be interpreted as dua tinggal dan dua pergi in Indonesian, in which students will form groups with several members. Some of the members will stay in the group and having the responsibility to deliver the material learned (can be in the form of posters, videos, clippings, etc.) to other group members who visit the group. The same goes with other groups; some of their members will have to go around and get information from other groups.

Rhiantini (2017) said this method encourages passive students to be more active because they need to move from place to place to exchange information which later will be delivered in front of the class. In this TS-TS method, students will rewrite, and retell the materials they have learned. This is in line with the literacy movement goals which not only encourage students to be able to read, but also write, change, summarize, modify, and retell the learning materials. Arif, et al (2016) also stated that the Two StayTwo Stray (TS-TS) method is a learning method that involves student interaction between groups and groups' members in the class. This method also provides an opportunity for the group to share information and solutions of their group with others (Dewi et al., 2016).

According to Wardono (2013), one of the attempts to improve student literacy is to innovate the teaching and learning process. The learning method that can be used to improve students' literacy skills is the cooperative learning method, which allows students to interact with each other, one of them is through the Two Stay-Two Stray (TSTS) method (Maonde et al., 2015). Septimarmisa et al (2018) said that this method teaches students to actively share information and respect the different opinions; students can also learn how to express their opinions to others. The confirmed and justified opinions by other students increase self-confidence and motivate students to express their ideas or opinion. Students will feel their existence important, even feel trusted, and respected, because, in a group, each member has an important role in their own assigned task (Sulisworo and Suryani, 2014).

Based on the previous explanation, the Two Stay-Two Stray method can improve students' scientific literacy because they do not only read but also write, express, and restate an opinion. It also boosts self-confidence and motivates students to keep applying scientific literacy. In this study, the application was chosen for respiration at 
The Development of Two Stay-Two Stray Cooperative Learning Instrument on Respiratory System to Improve Scientific Literacy Skills

basic competency or Kompetensi Dasar (KD) 3.8 and 4.8. One of the characteristics of respiration material is its relation to the ability to understand the concepts and principles of science to such an extent that students can apply them in everyday life. Students are expected to be able to explain and describe scientific phenomena based on scientific evidence. The respiratory system material has a contextual concept that is easy for students to find in everyday life. For example, a respiratory problem due to air pollution, smoking habits, etc. (Rusilowati, 2018). Aside from this topic being one of the important topics in Biology, this basic competency or KD is considered as one that fits the Two Stay-Two Stray method to practice Literacy skills. The skill in this particular competency is the skill in presenting the analysis results of the effect of air pollution on abnormalities in the human respiratory structure and function based on literature studies. From this competency, students are expected to analyze various problems regarding structural abnormalities of the respiratory organ function, which then the results of the discussion will be shared with other groups who come visiting their group. Therefore, there will be an exchange of information between groups.

According to PISA, scientific literacy has characteristics that will later appear in respiration material. The first one is to understand the key concepts of nature and interpret experiences in social, global, before selecting which contexts are relevant to real-life situations. The second one is to explain phenomena scientifically, such as applying scientific knowledge to certain situations, describing and interpreting those phenomena, etc. The third one is identifying scientific issues, the fourth one is to use scientific evidence, the fifth one is having an interest in science, such as the curiosity in science and its related issues, the sixth is to use a scientific approach in opinion, and the last one is showing concern toward the environment. From those characteristics, PISA has determined three scientific literacy indicators: content, context, and process. Thus, the research on development of a Two Stay-Two Stray (TS-TS) learning method on respiration material is needed to improve student's literacy skills (Aryani and Wibowo, 2016).

From the previous explanation, the formulation of the study is written using the questions: How is the validity of the Two Stay-Two Stray (TS-TS) learning tool on respiration material to improve scientific literacy skills?, how is the practicality of the Two Stay-Two Stray (TS-TS) learning tool on respiration material to practice scientific literacy skills? And how is the effectivity of learning tool seen from the scientific literacy ability of students taught in the Two Stay-Two Stray (TS-TS) method on respiration material and completeness of learning and sensitivity indicator on questions given regarding the materials?

The objective of the study is to produce a valid, practical, and effective Two StayTwo Stray (TS-TS) learning tool on respiration material to improve student's scientific literacy.

\section{RESEARCH METHOD} General Background

This research type is developmental research, as it aims to produce learning tools based on the Two Stay-Two Stray method to improve the scientific literacy skills of grade XI of senior high school students. The development method used is a 4D (Define, Design, Development, Disseminate) method. The examination was limited in using a one group 
The Development of Two Stay-Two Stray Cooperative Learning Instrument on Respiratory System to Improve Scientific Literacy Skills

pretest posttest design. The application of this method follows 4 stages of development: define, design, develop, and disseminate.

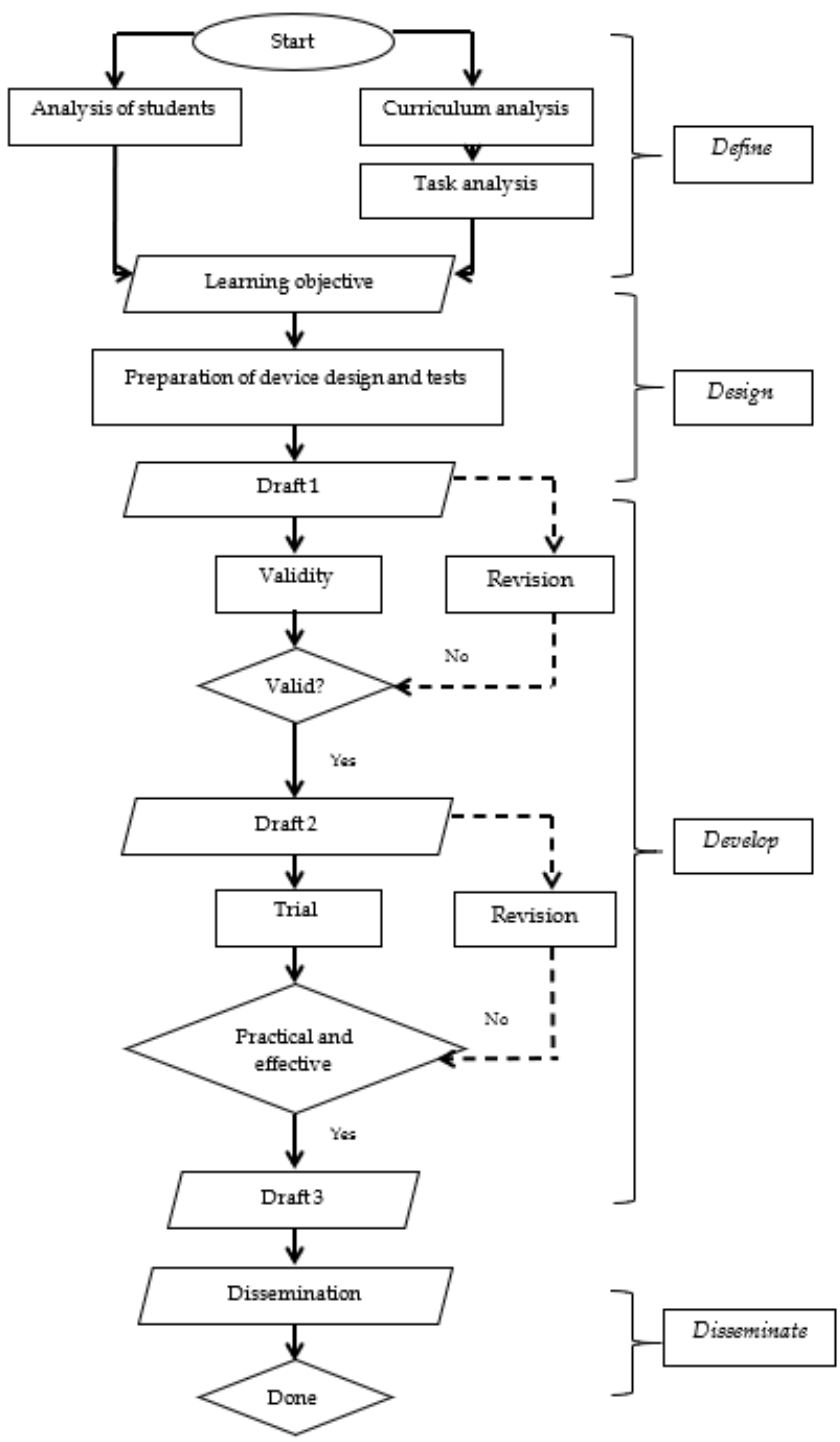

Figure 1. 4-D develompent model (Ibrahim, 2002).

\section{Sample}

Analysis of students is carried out at the beginning stage of planning by observing the students' characteristics, abilities, and experiences, both as individuals and groups. This stage's purpose is to find out students' ability toward the materials. The results of this analysis will be used as a reference in the preparation of the developed learning instrument.

The research would be conducted on 16 students of grade XI of SMAN 14 Surabaya with an age range of 16-17 years old, where they start to have a critical way of thinking at age range of 15-17 years old. On Piaget's theory, the cognitive development of teenagers around 12-17 years old has reached the stage of formal operations (mental activities about various ideas). Mentally, teenagers with this age range have been able to think logically about various abstract ideas. In other words, formal operational 
The Development of Two Stay-Two Stray Cooperative Learning Instrument on Respiratory System to Improve Scientific Literacy Skills

thinking is more hypothetical, abstract, systematic, and scientific than concrete thinking in solving problems (Ulinnuha and Indana, 2018).

\section{Instrument and Procedures}

The research instrument is a tool to obtain research data. It consists of an assessment sheet and a rubric. The instruments used in this study were instrument eligibility sheets, instrument implementation observation sheets, and student response questionnaire sheets for learning instruments on respiration material to improve literacy skills. (1) Lesson plan or RPP (Rencana Pelaksanaan Pembelajaran) and student worksheet or LKPD (Lembar Kerja Peserta Didik) eligibility validation sheet, in the form of a table containing content, presentation, and linguistic eligibility.

The validator fills the score column on a scale of 1-4 and provides written suggestions to the researcher. The validators are two postgraduate lecturers in the Department of Sciences Education or lecturers in the Department of Biology, University Negeri Surabaya. (2) The implementation observation determines the implementation of the developed instrument. (3) The student effectivity sheet contains statements addressed to students and observers after carrying out learning activities with the developed instrument. This sheet collects student response data regarding the effectivity of the developed instrument. The assessment sheet contains "yes" or "no" answer regarding the effectivity of the developed instrument. (4) The test sheet is an instrument or assessment sheet in the form of evaluation questions to find out student learning outcomes after using the developed learning instrument. This instrument records whether the students have completed or not completed their learning outcomes. It also determines the mastery learning indicators and the sensitivity of the question items. The mastery learning indicators is obtained from student learning outcomes, while the sensitivity of the question items is obtained through the analysis of the items used in the test sheet.

Data collection methods used are as follows: (1) Eligibility method. The eligibility sheet contains content, presentation, and language components. The review was carried out by a material expert lecturer and a biologist education expert. The review was done by giving a score of 1-4. The scoring category will be obtained through the average score, and the component score will be obtained through the mode score. (2) The implementation observation method is carried out by observing the teaching and learning process by the teacher and students during the developed learning activities with the help of the observer. (3) The questionnaire method is used to find out the students' obstacles while using the developed instrument. This questionnaire will be given once at the last meeting after the learning activities are all completed. Students fill the questionnaire with faithful answers individually. (4) The test method is used to determine student learning outcomes. The student learning outcomes obtained will be used to analyze the mastery learning indicators, while the question items in the test will be analyzed using item sensitivity to determine the characteristics of the items. The test sheet is given once at the last meeting after the learning activities are all completed.

\section{Data Analysis}

The data analysis technique used in this study is descriptive analysis: (1) The validity of the Two Stay Two Stray-based learning instrument is a level of quality of the learning 
The Development of Two Stay-Two Stray Cooperative Learning Instrument on Respiratory System to Improve Scientific Literacy Skills

instrument obtained from the eligibility results by a material expert lecturer and a biology education expert. The data obtained from each validator in the form of a score from each component include content, presentation, and language which consists of several criteria. The level of quality (validity) of each criterion on the developed learning instrument determines through the formula:

$$
\text { Score of each criterion }=\frac{\sum \text { the obtained criterion score }}{\Sigma \text { numbers of validator }}
$$

Through these data, the validity level of the student worksheet or LKPD (Lembar Kerja Peserta Didik) can be known in terms of each component by using a score of each component its means modus score from each criterion. Through the result of eligibility analysis, four score criteria will be obtained in Table 1.

Table 1. Eligibility criteria for mean value analysis.

\begin{tabular}{cc}
\hline Mean & Eligibility category \\
\hline $1,00-1,75$ & Not Feasible \\
$1,76-2,50$ & Inadequate \\
$2,51-3,25$ & Decent \\
$3,26-4,00$ & Very Decent \\
\hline & (Adapted from Riduwan, 2013)
\end{tabular}

The validity of the Two Stay-Two Stray learning instrument can be seen from the data analysis technique. The Two Stay Two Stray learning instrument is proved to be valid and can be used as a learning medium if the average score is $\geq 3.26$. The next step is to calculate the reliability of validity with the following calculations:

$$
r_{11}=\left(\frac{n}{n-1}\right)\left(1-\frac{\Sigma \sigma_{t}^{2}}{\sigma_{t}^{2}}\right)
$$

Description:

$\mathrm{r}_{11} \quad$ : Reability of the instrument

$\mathrm{n} \quad$ : total of question items

$\Sigma \sigma_{t}^{2} \quad$ : total of items' variant

$\sigma_{t}^{2} \quad$ : total of variant

$$
\text { Performance score }=\frac{\sum \text { the obtained criterion score "yes" answer }}{\Sigma \text { performance criterion }}
$$

Analysis technique (3) The effectivity of the developed Two Stay-Two Stray learning instrument can be measured using the mastery learning objectives, and the sensitivity of the question items. Student learning outcomes are obtained through the test (evaluation). Student learning outcomes can be measured by comparing the scores obtained by students with the minimum mastery standard or Skala Ketuntasan Minimal (SKM) that has been set by the school for Biology subjects, which is 75. Students are considered to have already mastering the material if their outcome score is $\geq 75$. The 
The Development of Two Stay-Two Stray Cooperative Learning Instrument on Respiratory System to Improve Scientific Literacy Skills

mastery learning indicators is showed through the mastery of each learning objective which is determined by a calculation.

$\%$ Mastery learning objective $=\frac{\sum \text { students who got a correct answer }}{\Sigma \text { all students }}$

The sensitivity of the question items is evaluated through analyzing the question items regarding the criteria from the sensitivity index. The item sensitivity index shows the effectivity of the teaching and learning process which is determined by the formula:

$$
I S B=\frac{R a-R b}{n}
$$

ISB (indeks sensitivitas butir soal) is the item sensitivity index, $\mathrm{Ra}$ is the number of students who can do the question items after using the developed LKPD (post-test), Rb is the number of students who can do the question items before using the developed LKPD (pre-test), and $\mathrm{N}$ for the total number of students. The sensitivity of the question items can be determined by analyzing the items used in the evaluation test to obtain student learning outcomes after using the developed LKPD. A test item is considered sensitive if the sensitivity index (ISB) is $>0.30$.

Analysis technique (4) Test analysis for scientific literacy skills and student learning outcomes shows through the results of pretest, posttest, and calculated by N-gain. Gain is the subtraction result between the pretest and posttest scores to show the quality of the students' scientific literacy skills improvement and learning outcomes. N-gain (normalized gain) is used to measure the increase in students' scientific literacy skills and learning outcomes before and after learning (Sundayana, 2014). To find out the Ngain, the following formula is used:

Description:

$$
g=\frac{\%<S f>-\%<S i>}{\%<S \text { maks }>-\%<S i>} \times 100 \%
$$

Sf : final score (post-test)

Si : initial score (pre-test)

Smax : maximum score that can be achieved

Table 2. Gain criteria.

\begin{tabular}{c|c}
\hline Gain score & Interpretation \\
\hline $0,70 \leq \mathrm{g} \leq 100$ & High \\
$0,30 \leq \mathrm{g}<0,70$ & Average \\
$0,00<\mathrm{g}, 0,30$ & Low \\
$\mathrm{g}=0,00$ & Stable \\
$-1,00 \leq \mathrm{g}<0,00$ & Decrease \\
\hline
\end{tabular}

(Adapted from Sundayana, 2014)

\section{RESULTS AND DISCUSSION}

The eligibility of implementation the lesson plan was tested on 16 students online. This lesson plan is used as a reference for the teaching and learning process to achieve the basic competencies on the respiratory system material. The KD 3.8: the respiratory system concerning bioprocesses and functional disorders in human respiratory system. 
The Development of Two Stay-Two Stray Cooperative Learning Instrument on Respiratory System to Improve Scientific Literacy Skills

It also stated in KD 4.8: presenting the analysis results of the effect of air pollution on abnormalities in the human respiratory structure and function based on literature studies.

The learning method applied to this lesson plan is the Two Stay-Two Stray method with the improvement of students' scientific literacy as the objective. The method is a cooperative method which support the literacy movement. The Two Stay-Two Stray method can be interpreted as dua tinggal dan dua pergi in Indonesian, in which students will form groups with several members. Some of the members will stay in the group and having the responsibility to deliver the material learned (can be in the form of posters, videos, clippings, etc.) to other group members who visit the group. The same goes with other groups; some of their members will have to go around and get information from other groups.

Rhiantini (2017) said this method encourages passive students to be more active because they need to move from place to place to exchange information which later will be delivered in front of the class. In this TS-TS method, students will rewrite, and retell the materials they have learned. This is in line with the literacy movement goals which not only encourage students to be able to read, but also write, change, summarize, modify, and retell the learning materials. Arif, et al (2016) also stated that the Two StayTwo Stray (TS-TS) method is a learning method that involves student interaction between groups and groups' members in the class. This method also provides an opportunity for the group to share information and solutions of their group with others (Dewi et al., 2016).

The learning indicators and objectives in this lesson plan have been adjusted to the indicators to improve scientific literacy. The steps and assessment in the form of posters have been adapted to the Two Stay-Two Stray method and are also adjusted to the indicators.

There are 2 lecturers; 1 education expert lecturer and 1 material expert lecturer, who will validate the eligibility of the developed lesson plan (RPP). There are five criteria that must be scored: the identity of the lesson plan, formulation of learning objectives, content presented, language, and time. The perfect score for each criterion is 4; a score of 4 if the assessment results agree to the description written in the assessed aspect column, a score of 3 if most of the validation results agree to the description, a score of 2 if most of the validation results are disagree to the description, and a score of 1 if the assessment results completely disagree to the description in the observed aspect column for each validated aspect.

Table 3. Results recapitulation of the validation.

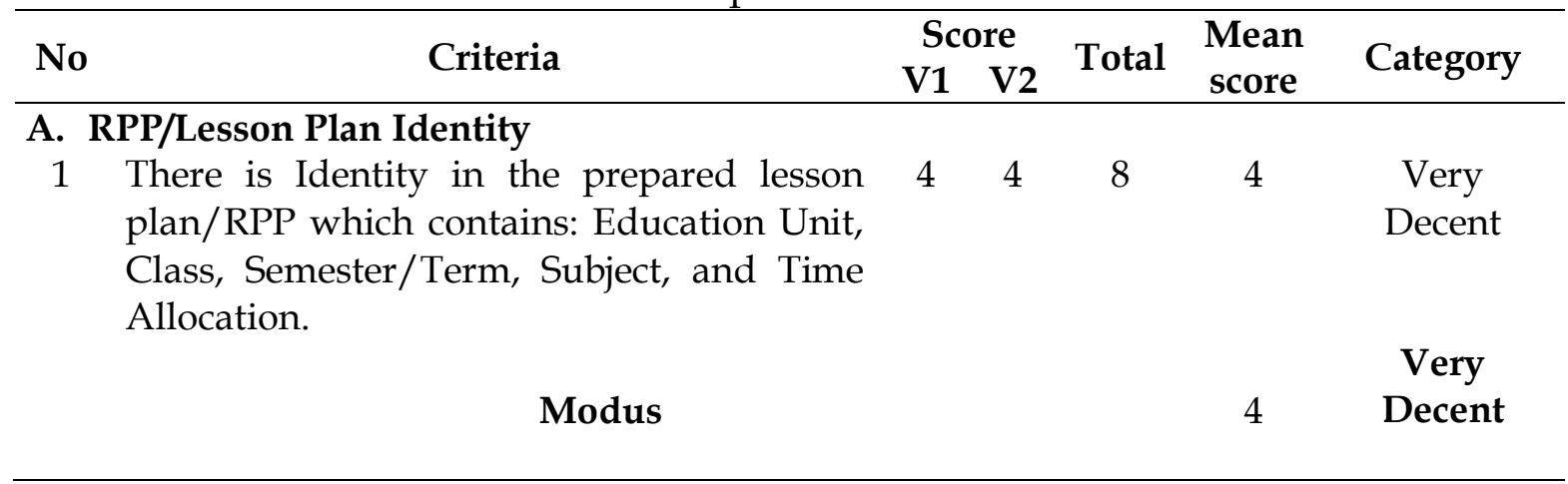


The Development of Two Stay-Two Stray Cooperative Learning Instrument on Respiratory System to Improve Scientific Literacy Skills

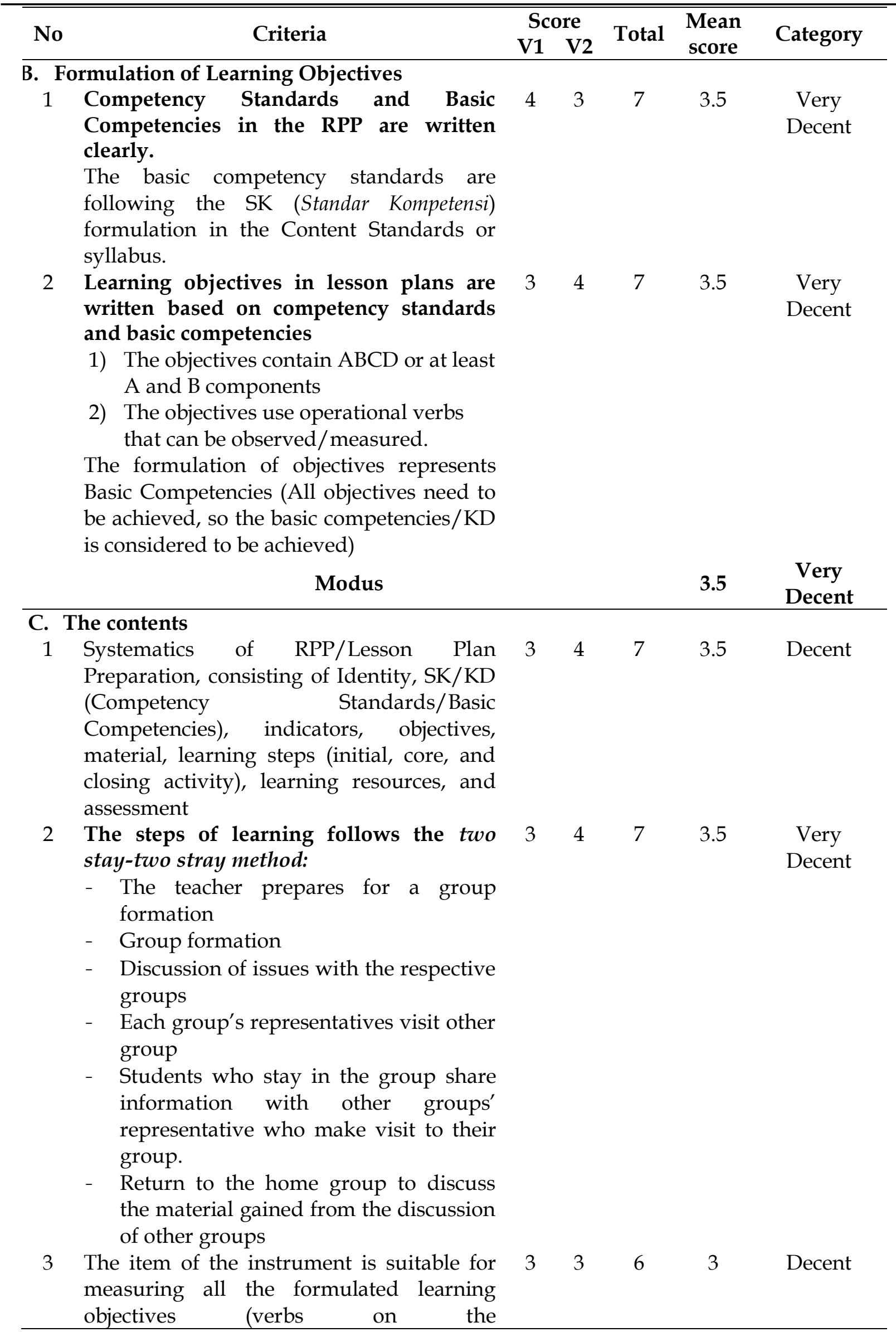


The Development of Two Stay-Two Stray Cooperative Learning Instrument on Respiratory System to Improve Scientific Literacy Skills

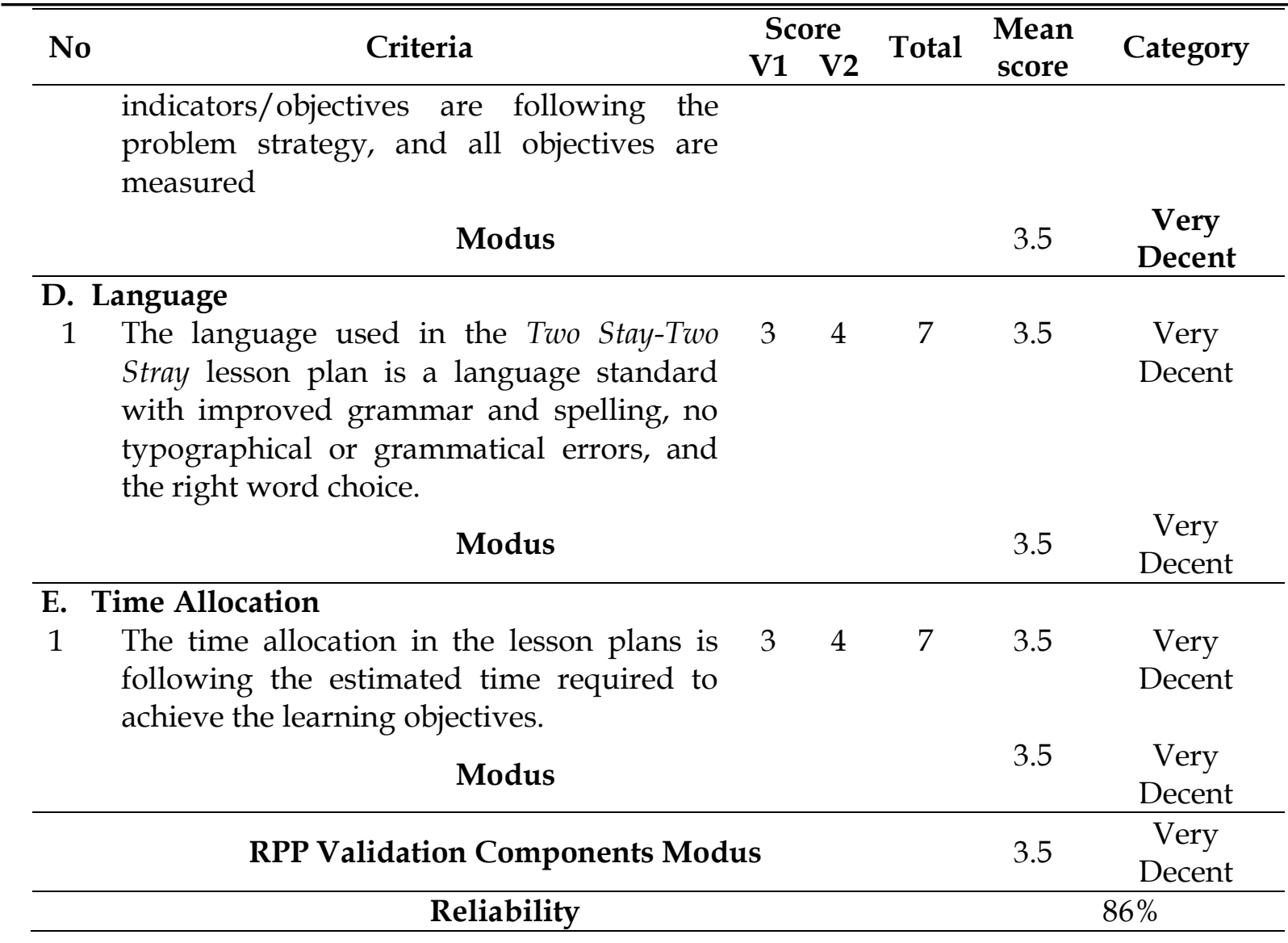

Based on the results of the validation, it was found that the lesson plan (RPP) got the mean value on each component of 3.5 which according to Riduwan (2013) number was in very decent category. Wiryanti (2017) stated that the preparation of the identity of the RPP was agreeing to the provisions of Permendikbud No. 22 of 2016 regarding the standard process for primary and secondary education which consists of school identity, subject identity, class/term as stated by Wahidmurni (2020). The formulation of learning objectives prepared is agreeing to the competency in the standard content or syllabus, the content presented is agreeing with Permendikbud No. 22 of 2016 in terms of the systematic preparation of the RPP. The development of this lesson plan also facilitates students to practice scientific literacy using the Two Stay-Two Stray learning method, the language used is appropriate because its development is based on the Indonesian spelling system or EYD (Ejaan yang Disempurnakan) so the language is communicative and easy to understand, and the time used is agreeing to the provisions.

Aside from this lesson plan or RPP being in the very decent category, it also has a reliability value of $86 \%$. Reliability is a test that shows the consistency of results in the assessment process in the form of accuracy and thoroughness (Dewi et al., 2020). If the reliability value is $75 \%$, the RPP that has been developed is considered eligible to be used in the teaching and learning process (Arsanty and Wiyatmo, 2017).

The lesson plan or RPP is considered to be eligible if the preparation is based on Permendikbud No. 22 Tahun 2016 Tentang Standar Proses. The principles that must be considered in preparing lesson plans are: (1) individual differences of students, (2) active participation of students, (3) student-centered to encourage enthusiasm for learning, motivation, interest, creativity, initiative, inspiration, innovation, and 
The Development of Two Stay-Two Stray Cooperative Learning Instrument on Respiratory System to Improve Scientific Literacy Skills

independence, (4) Development of reading and writing culture to develop a reading habit, understanding of various readings, and expression in various forms of writing, (5) Providing feedback and follow-up to RPP which provide positive feedback, reinforcement, enrichment, and remedies, (6) Covering subjects, aspects of learning, and cultural diversity, (7) the application of integrated, systematic, and effective manner of information and communication technology according to the terms and conditions (Khairani, 2020).

The eligibility of the student worksheet or LKPD in the teaching and learning process is used to improve students' scientific literacy through the Two Stay-Two Stray learning method. The Two Stay-Two Stray learning method according to Dewi et al (2016) has the following procedures: (1) one group consists of 4 students who will cooperate. At this stage the LKPD has been given to check the students' initial knowledge about the respiratory system material and what information they want to get with questions such as "what do you know?" and "what do you want to know." The questions made in this LKPD refer to the school literacy movement or Gerakan Literasi Sekolah (GLS) book (Sutrianto et al., 2016).

The indicator/aspect of scientific literacy taught at this stage is the content. According to Aryani and Wibowo (2016), the aspect can be taught through the subjects learned by students to core facts, concepts, theories, procedures, and explanations of frameworks that organize, relate ideas, and how to do things coherently. In this case, there are two limitations: the material of the school science curriculum, and the knowledge obtained from other sources.

The next procedure, (2) After completing the task, two students from each group will have to leave and start visiting other groups. At this stage, students will collect information from other groups and fill in answers to the question "what have you learned?." The indicator/aspect of scientific literacy taught at this stage is the context. These indicators refer to conditions in everyday life and become a reference for the application of understanding scientific concepts. Aryani and Wibowo (2016) revealed that these indicators/context aspects can improve scientific literacy by referring more to everyday life, which involves important issues such as personal care.

In the next procedure (3) two students who remain in their respective groups will share the results of their work to two students who come visiting. At this stage, the aspect/indicator of scientific literacy taught is a process, where students are answering a question or solving problems, such as analyzing, explaining evidence, and drawing conclusions. This aspect/indicator refers to a mental process where students answer a question/solve a problem, such as identifying and interpreting evidence (Aryani and Wibowo, 2016).

The next procedure (4) two students who visit can return to their groups and report the results they get from other groups, (5) cross-check and discuss the results of their work. In stages 4 and 5, the indicators/aspects of scientific literacy taught are also part of indicator of process.

The worksheet or LKPD that has been created must go through a validation process to determine whether it is eligible and suitable for use in the teaching and learning process. The validator is given an LKPD validation sheet which contains two aspects to be assessed. The first aspect is the suitability of the content by obtaining a mode score of 4 with very decent criteria. This result indicates that the contents and the biological terms of the worksheet are correct and agree with the concept. According to Herdianawati et al (2013) the LKPD material can be in the form of supporting information; an overview or scope of the substance to be studied and the material listed must be agreeing with $\mathrm{KI}$ and KD, suitable with students' abilities, and learning 
The Development of Two Stay-Two Stray Cooperative Learning Instrument on Respiratory System to Improve Scientific Literacy Skills

objectives so the students find the material easy to understand and make them more active, and feel encouraged to practice their social skills.

The second aspect is the presentation, It obtains a mode score of 4 with very decent criteria. This result indicates that the display of color selected makes students feel enthusiastic in working on LKPD since the LKPD is presented in an attractive form. The type of writing or font is clear, and the spelling is correct. A good LKPD meets the requirements of the good use of language, sentence structure, vocabulary, level of difficulty, and lessons that essentially must be effective in a sense, so it can be understood by students. The mode score obtained from the average or mean score of each component of this LKPD eligibility is 4 with very decent criteria and $77 \%$ of reliability which is considered eligible to be used in the teaching and learning process (Arsanty and Wiyatmo, 2017).

The last validation of eligibility of the instrument is a test. This test is created to find out student learning outcomes after learning with the developed learning instrument. This test consists of a pre-test given before the teaching and learning process begins. This test determines students' initial abilities. The second one is a post-test given at the end of the lesson to find out student learning outcomes after learning with the Two StayTwo Stray method regarding improvement of scientific literacy. According to Supardi (2015) the test is a systematic, comprehensive, and objective evaluation procedure so the results can be used as a basis for making learning decisions made by the teacher.

The test is made from the basic competency (KD) indicators that have been integrated to improve scientific literacy. The total pre-test and post-test questions are 10 essay questions with cognitive levels between C4 to C5 according to the Ministry of National Education or Depdiknas (2013) which stated that the cognitive at the high school (SMA) level is an achievement in the ability to analyze (C4), evaluate (C5) and create. The indicators/aspects of scientific literacy included in this test are context, content, and process.

The characteristics of a good test according to Zainab et al (2017) are eligibility and reliability. A test is considered to be valid/eligible if it agrees with the real situation. The eligibility of the content is proved through how far the test is carried out on its content to represent the sample given by the test proportionally. While reliability is a test that can be trusted if it gives a constant result, although the test is repeated. Reliability is the accuracy of the test.

The eligibility test of pre-test and post-test were carried out by two validators; one education expert lecturer and one material expert lecturer. There are three criteria that need to be assessed: content, presentation, and language. The content criteria consist of no misconceptions, clear instructions for filling out, an assessment that agrees with material indicators that have been prepared through KD elaboration, and preparation of questions that agree with scientific literacy indicators. In this criterion, the mode score is obtained from the mean score of each category/item of 4 which is the part of a very decent category. The presentation criteria consist of numbering, and the use of fonts which obtained a mode score of 3.5 with a very decent category. The last criterion is the language which obtained a score of 3.5, which is a very decent category.

The results of the pre-test and post-test eligibility tests obtains a score of 3.5 which according to Riduwan (2013) the number falls into the very decent category, while the test is considered to be reliable if the reliability value is $\geq 75 \%$ so the pre-test and post- 
The Development of Two Stay-Two Stray Cooperative Learning Instrument on Respiratory System to Improve Scientific Literacy Skills

test that have been developed are considered to be eligible to use in the teaching and learning process (Arsanty and Wiyatmo, 2017).

Table 4. Compilation result of the learning instrument validation.

\begin{tabular}{ccc}
\hline Learning instrument & Validation category & Reliability value \\
\hline RPP (lesson plan) & very decent category & $86 \%$ \\
LKPD (student worksheet) & very decent category & $77 \%$ \\
Pre-test & very decent category & $94 \%$ \\
Post-test & very decent category & $94 \%$ \\
\hline
\end{tabular}

The practicality of the learning instrument (RPP) is determined through its implementation. Observation of the implementation is done by observing the teaching and learning process by the teacher using the developed learning instrument with the help of the observer and the response sheets which will be given to the students after participating in the entire process of teaching and learning activities.

Observation of the performance is carried out to see the implementation of the RPP and LKPD which will be given and filled out two times/each meeting. The performance of the lesson plans is part of the learning planning. According to Trisnawati et al (2016), the criteria for implementing the observed learning are in the form of introduction, content, and closing.

Activities in the lesson plan sequentially are opening lessons by greeting, student representatives leading the prayer, teachers checking attendance, conducting apperception activities, delivering learning objectives, preparing activities, such as showing videos, conducting group activities, monitoring group performance (Including discussing issues in each group, visiting other groups, sharing information with other groups, returning to the respective group to discuss what they learned).

Preliminary activities in the lesson plan are the initial activities of learning. In the preliminary activities, the teacher must be able to attract students' interest in the material being taught. Preliminary activities that are presented interestingly will increase students' learning motivation. The activity used to attract students' attention is to show videos at the beginning of learning so the online learning will not be boring. Oakley and Sejnowski (2019) said to make online classes students put interest in participating, an important element of online learning that can attract students' attention is tutorial videos. Next, the main activity is the important part of the learning activity. In this activity, the teacher provides further information about the material using the Two Stay-Two Stray method. The last activity is closing which provides feedback to check student understanding and follow-up assignments for the next meeting.

These activities were all carried out during the first and second meetings and obtaining a $100 \%$ performance/implementation score percentage. The lesson plans are used as a reference for the learning process to achieve basic competencies. Teachers in the education unit are obliged to prepare lesson plans systematically so the teaching and learning process will be interactive, inspiring, fun, challenging, encouraging students to participate actively, and provide sufficient space for initiative, creativity, and independence following the talents, interests, physical, and psychological development of students (Suprihatiningrum, 2012). 
The Development of Two Stay-Two Stray Cooperative Learning Instrument on Respiratory System to Improve Scientific Literacy Skills

The practicality of the second learning device is seen from the performance of the LKPD. LKPD is a learning media containing questions or instructions for completing certain tasks (Yaumi, 2018). LKPD contains a set of basic activities to maximize understanding to form the basic abilities of students according to indicators of learning outcomes achievement (Trianto, 2012). Trianto (2012) also stated that LKPD is a guide for the development of cognitive and learning aspects in the form of experimental or demonstration assistance.

Through the result of the performance score, at the first meeting, the LKPD reached $95.3 \%$ and at the second meeting, it increased to $98.4 \%$. According to Nainggolan and Erlinawaty (2019), LKPD is considered practical if it meets the target results of the implementation of learning by observers, which is in the range of $70 \%$ to $85 \%$. In other words, the LKPD at meetings 1 and 2 is considered to be practical. In addition, the response of students' barriers to LKPD has a score in the range of $75 \%-100 \%$. Students have several obstacles including a lot of material to be learned, According to Dewi and Widodo (2017) in the respiratory system material, students are required to completely understand the structure of the respiratory organs, the process of respiration; includes the one in the alveoli, to several diseases in the respiratory organs. Fundamentally, this material focuses not only on the anatomy of organs but also their physiology so it's unavoidable for students to find it difficult in understanding the material.

In addition to the condition where the teaching and learning activity is done onlin, the time allocation is limited. Aside from the time allocation problem, students also expressed their difficulty in connection problems when they were learning through the Zoom application. According to Utomo et al (2021) there are many obstacles in doing online teaching and learning activitis, one of them come from the internet network where not everyone has the same internet speed. Another response regarding learning instrument is that in working on the Student Worksheet (LKPD), there are some students who have difficulty filling out the worksheet since the answers need to be written Ms. Words.

Table 5. The practicality of the learning instrument.

\begin{tabular}{cc}
\hline Learning instrument & The practicality value \\
\hline RPP (lesson plan) at first meeting & $100 \%$ \\
RPP (lesson plan) at second meeting & $100 \%$ \\
LKPD (student worksheet) at first meeting & $95.3 \%$ \\
LKPD (student worksheet) at second meeting & $98.4 \%$ \\
\hline
\end{tabular}

The effectivity of the learning instrument is showed from the achievement of the indicators and the sensitivity level of the question items. Based on the achievement of the learning indicators on the pre-test questions, there are 3 incomplete indicators: the indicator to identifies the function of each organ of the human respiratory system; at least 4 functions of the respiratory system correctly after listening to the teacher's explanation and discussing it with a performance score of $62.5 \%$, then the indicator to identifies the various air volumes in human respiration; at least 4 kinds of air volume correctly after listening to the teacher's explanation and discussing with a performance score of $62.5 \%$. 
The Development of Two Stay-Two Stray Cooperative Learning Instrument on Respiratory System to Improve Scientific Literacy Skills

The two indicators in the pre-test and post-test questions are shown in the form of pictures and students need to name the part of the organ. In the pre-test that was carried out before the students get the material, they were still confused, had wrong concepts or even misconceptions. According to Ritonga et al (2017) the misconceptions can be formed from students' minds on their limited understanding of the natural surroundings or other sources that cannot be justified. From this statement, it concludes that scientific literacy in the aspects/indicators of content is still lacking. These indicators are key concepts that are needed to understand concerning the natural phenomena and changes that occur in the environment caused by human activities. There are two limitations in this case which are the material of the school science curriculum, and the knowledge obtained from other sources.

The last indicator is to analyze the causes of respiratory system disorders. at least 4 disorders correctly after discussion with a performance score of $62.5 \%$; this could be affected by the lack of reading literature/news about health. On these indicators, the unfinished aspect of scientific literacy is a context indicator that refers to conditions in everyday life. This becomes a reference for the application of understanding scientific concepts.

The results of the next indicator in the post-test questions all learning indicators are successfully achieved with a score between $75 \%$ to $93.75 \%$. The students have followed the lesson and received feedback from the teacher. Feedback is related to actions or information provided by the teacher about performance and understanding aspects of the student. Feedback is information about the gap between what has been understood, what is meant to be understood, and what the next action should be taken. It encourages the increase of motivation or engagement efforts to achieve the goals, provides information about alternative strategies for understanding the material, confirms the right and wrong one to students, how far they have reached the goal, etc.

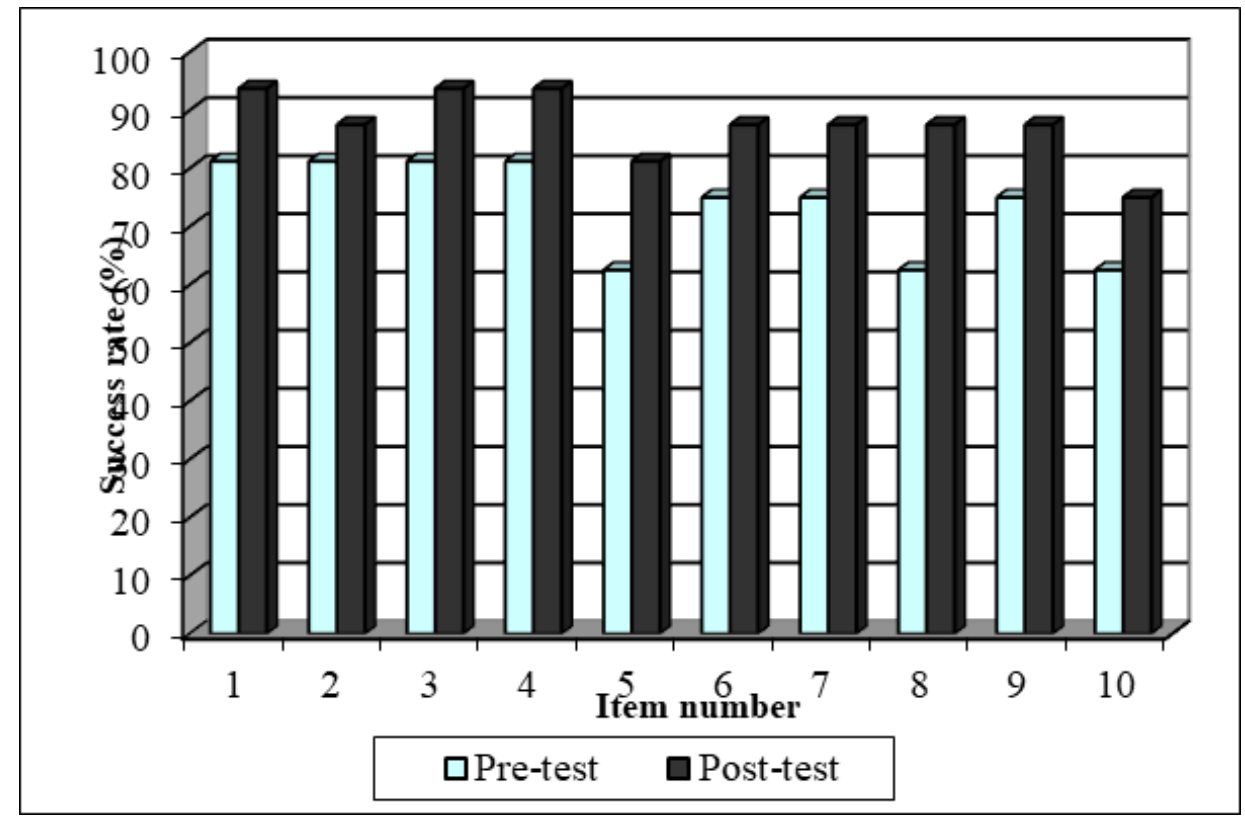

Figure 2. Score of pre-test and post-test. 
The Development of Two Stay-Two Stray Cooperative Learning Instrument on Respiratory System to Improve Scientific Literacy Skills

The results of the students pretest and posttest were analyzed using SPSS to determine the effect of using implementation of the development of two stay-two stray cooperative learning to improve scientific literacy skills. These result show in Table 6.

Table 6. The result of normality test, homogeny test and paired sample t-test.

\begin{tabular}{cccc}
\hline \multirow{2}{*}{ Statistic parameter } & \multicolumn{3}{c}{ Score } \\
\cline { 2 - 4 } & Pre-test & & Post-test \\
\hline Mean & 75.73 & 03.74 \\
Normality test & & 0.308 & \\
Homogeneity test & & 0.785 & \\
Paired sample t-test & & 0.000 & \\
\hline
\end{tabular}

According to table 6, value of sig. normality test is $0.308>0.05$ indicating that the data normally distributed. A sig. value of homogeneity test is $0.785>0.05$ indicating that the data was homogeneous and could be used for statistical test. The last statistical parameter is paired sample t-test that yielded a sign of $0.000<0.05$ its means there is an effect of using implementation of the development of two stay-two stray cooperative learning to improve scientific literacy skills. Fitriyani and Afriana (2016) explain that two stay-two stray cooperative learning is effective to improve literacy skills because it can encourage group members to solve real problems through giving students roles. Students are invited to work together in groups so that it will direct students to actively discuss, seek answers, explain and pay attention to the presentations of other groups.

The sensitivity of the test is calculated to determine the effect of learning. The sensitivity index of question items is a measure of how well the item distinguishes between students who have received and students who have not received the developed learning method (Murti, 2016). An item is considered to be sensitive if it has a score of 0.30 . From the results (table 4.10) all questions compiled from learning indicators fall into the sensitive category, which has a score of 0.30 .

Student learning outcomes can be measured using tests to evaluate students' mastery of learning in each competency, such as in the learning process, daily tests, and semester exams. The measurement often uses evaluation in the form of tests. The test of learning outcomes is to measure the behavior change in the learning objectives achieved by students. The developed test instrument is focused on the dimensions of cognitive processes: remembering is taking knowledge from long-term memory, understanding is constructing meaning from learning material, applying is using procedures in certain circumstances, analyzing is breaking material into smaller parts and determining the relation between parts and the structure as a whole, evaluating is making decisions based on criteria and standards, and creating is the process of arranging the elements of a coherent or functional whole (Zufadli, 2017). 
The Development of Two Stay-Two Stray Cooperative Learning Instrument on Respiratory System to Improve Scientific Literacy Skills

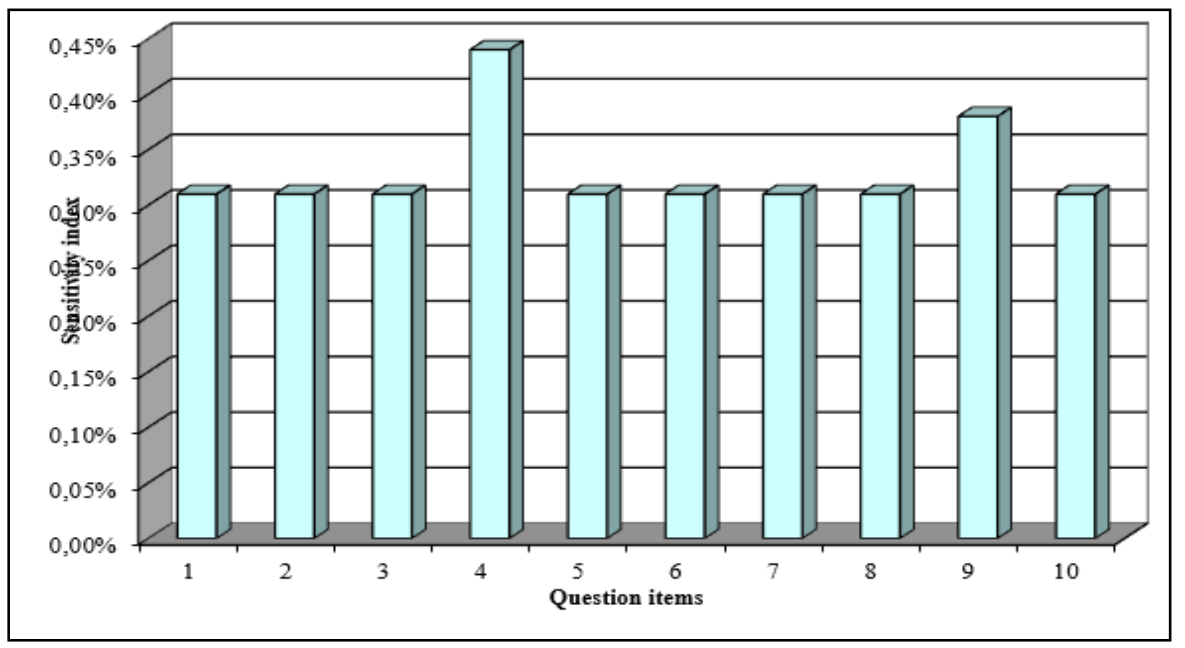

Figure 3. The sensitivity index of question items.

Before doing teaching and learning activities using the Two Stay-Two Stray method, students get a pre-test question and get a post-test after the activity. The scores obtained will show the quality of scientific literacy as well as student learning outcomes. The calculation result using the gain score is the difference between the pre-test and posttest scores. Based on the recap of the pre-test scores, 5 out of 16 students did not pass this test. This might be caused since students have not been taught the material for vibration of the respiratory system, so students have difficulty in working on the pretest questions (Nirmalasari et al., 2016).

The results that have been obtained show that there is only 1 student out of a total of 16 students who get low literacy scores and learning outcomes with an n-gain (g) value of 0.12 . This may have many factors, some of them are the teacher's observations, the student lacks discipline in the online learning room which causes information about learning to be left behind, students are seen doing other activities besides learning so it interferes concentration during the learning process. According to Nirmalasari et al (2016) students pay less attention to the learning material conveyed by the teacher because the concentration was divided. Since the teaching and learning activity is done online, it also affects the level of student understanding and the focus of students when doing the given tests.

There are 11 students who have high n-gain scores $(\mathrm{g})$ or literacy scores and learning outcomes, 4 students who get medium literacy scores, learning outcomes, and n-gain (g) scores. The medium category in the value of $\mathrm{N}$ gain in scientific literacy skills is caused by a number of factors, including the results of the analysis during the pretest activity and interview with teachers and student representatives, which revealed that students were not used to working on the form of scientific literacy skills. Science literacy skill questions do require reasoning and the application of science to understand the questions. (Dewi et al., 2021). The quality of education can be improved by marking a good literacy score, especially scientific literacy. Literacy scores are high if students from an early age can understand the cause and effect of natural phenomena by reading various literatures (Saraswati et al., 2021). 
The Development of Two Stay-Two Stray Cooperative Learning Instrument on Respiratory System to Improve Scientific Literacy Skills

\section{CONCLUSIONS}

From the formulation of the implementation from development research problem, research objectives, research results, and discussion, the conclusion is to produce a valid, practical, and effective learning instrument using the Two Stay-Two Stray method on respiratory system to improve scientific literacy skills. The implementation of this develompment can be implied by being used as one of the supporting media for Biology subjects on respiratory system, one of the media to support students in practicing literacy science. The author suggests that it is necessary to development such as with different materials.

\section{ACKNOWLEDGMENTS}

The researcher would like to thank lecturer Dr. Raharjo, M.Si., and Dr.sc.agr.Yuni Sri Rahayu, M.Sc., as validators who have provided corrections and suggestions for this implementation and students of class XI IPA 2 in 14 Surabaya senior high school who have been willing to help this research.

\section{REFERENCES}

Arif, N., Soetjipto, B. E., \& Degeng, I. N. S. (2016). The implementation of carousel feedback and two stay two stray learning models to enhance students' self efficacy and social studieslearning outcome. IOSR Journal Of Humanities And Social Science (IOSR-JHSS), 21(5), 99-104. https://doi.org/10.9790/0837-21050399104

Arsanty, V. N., \& Wiyatmo, Y. (2017). Pengembangan perangkat pembelajaran fisika berbasis model pembelajaran sts dalam peningkatan penguasaan materi dan pencapaian kreativitas peserta didik SMA. Jurnal Pendidikan Fisika, 6(1), 23-32.

Aryani, A. K., \& Suwono, H. (2016). Profil kemampuan literasi sains. Seminar Nasional Pendidikan IPA Pascasarjana 1(1), 1-7.

Depdiknas. (2013). Peraturan menteri pendidikan dan kebudayaan republik indonesia nomor 66 tahun 2013. Jakarta: Departemen Pendidikan Nasional Republik Indonesia.

Dewi, F. D. R., Soetjipto, E. B., \& Utaya, S. (2016). The implementation of tsts and round robin learning models to enhance communication skill and social studies learning outcome for the fourth grade students. IOSR Journal of Research and Method Education, 6(1), 93-100.

Dewi, N. P., Rahmi, Y. L., Alberida, H., \& Drussyamsu, R. (2020). Validitas dan reliabilitas instrumen penilaian kemampuan berpikir tingkat tinggi tentang materi hereditas untuk peserta didik SMA/MA. JEP (Jurnal Eksakta Pendidikan), 4(2), 138-146. https://doi.org/10.24036/jep/vol4-iss2/512

Dewi, S. P., \& Widodo, A. (2017). Analisis konsepsi siswa dalam materi sistem respirasi. Seminar Nasional Pendidikan IPA, 1(1), 1-8.

Dewi, V. C., Susantini, E., \& Poedjiastoeti, S. (2021). The use of biology textbook based on collaborative learning model to improve scientific literacy skill. IJORER: International Journal of Recent Educational Research, 2(4), 444-454. https://doi.org/10.46245/ijorer.v2i4.130

Fitriyani, I., \& Afriana, Q. H. (2017). Keefektifan pembelajaran kooperatif tsts dengan bermain peran terhadap kemampuan literasi matematika. PRISMA: Prosiding Seminar Nasional Matematika, 1(1), 248-256.

Herdianawati, S., Fitrihidajati, H., \& Purnomo, T. (2013). Pengembangan lembar kegiatan siswa (lks) inkuiri berbasis berfikir kritis pada materi daur biogeokimia kelas X. Jurnal Pendidikan Biologi, 2(1), 99-104. 
The Development of Two Stay-Two Stray Cooperative Learning Instrument on Respiratory System to Improve Scientific Literacy Skills

Herdiani, A. (2013). Pengaruh pembelajaran inquiry lesson terhadap peningkatan kemampuan literasi sains dan sikap ilmiah siswa SMP pada materi fotosintesis. Tesis: Universitas Pendidikan Indonesia.

Ibrahim, M. (2002). Pengembangan perangkat pembelajaran. Jakarta: Depdiknas

Khairani. (2020). Workshop peningkatan kemampuan guru dalam penyusunan RPP. Jurnal Kinerja Kependidikan Facilities of Education Career and Educational Scientific Information, 2(3), 273-285.

Maonde, F., Bey A., \& Salam M. (2015). The discrepancy of students' mathemathic achievement through cooperative learning model and the ability ini mastering languages and science. International Journal of Educational and Research, 3(1), 141-159.

Murti, S. C. C. (2016). Pengembangan perangkat pembelajaran ipa model learning cycle 7e untuk melatihkan keterampilan penyelesaian masalah siswa pada pokok bahasan kalor di smpn 2 banyuwangi. JURNAL PEMBELAJARAN FISIKA, 4(5), 701-716.

Nainggolan, D. A. Y., \& Erlinawaty, S. (2020). Pengembangan lembar kerja peserta didik (LKPD) berbasis pendekatan metakognitif pada materi pola bilangan. IBONACI: Jurnal Pendidikan Matematika, 1(1), 1-12. https://doi.org/10.24114/jfi.v1i1.19064

Nirmalasari, Santiani, \& Rohmadi, M. Penerapan model pembelajaran learning cycle terhadap keterampilan proses sains dan hasil belajar siswa pada pokok bahasan getaran harmonis. EduSains, 4(2), 74-94. https://doi.org/10.23971/eds.v4i2.511

Nofiana, M., \& Julianto, T. (2018). Upaya peningkatan literasi sains siswa melalui pembelajaran berbasis keunggulan lokal. Biosfer: Jurnal Tadris Biologi, 9(1), 24-35. https://doi.org/10.24042/biosf.v9i1.2876

Nurjannah, A., Sudin, A., \& Sujana, A. (2017). Literasi sains dalam pembelajaran berbasis masalah (penelitian pre-experimental terhadap siswa kelompok atas, tengah, dan bawah sdn waringin ii dan sdn palasah i di kecamatan palasah kabupaten majalengka pada materi energi panas). Jurnal Pena Ilmiah, 2(1), 581-590. https://doi.org/10.17509/jpi.v2i1.10036

Oakley, B. A., \& Sejnowski, T. J. (2019). What we learned from creating one of the world's most popular MOOCs. Npj Science of Learning, 4(1), 1-7. https://doi.org/10.1038/s41539-0190046-0

Rhiantini. (2017). Penerapan metode two stay two stray dalam upaya meningkatkan keterampilan menulis pada materi laporan pengamatan. Jurnal Pena Ilmiah, 2(1), 121-130.

Ritonga, N., Gultom, H. S. B., \& Sari, N. F. (2018). Miskonsepsi siswa biologi tentang materi sistem respirasi pada sma negeri se-kabupaten labuhanbatu. Jurnal Pelita pendidikan, 6(1), 42-46. https:// doi.org/10.24114/jpp.v6i1.9172

Rusilowati, A. (2018). Asesmen literasi sains: Analisis karakteristik instrumen dan kemampuan siswa menggunakan teori modern rasch model. Prosiding Seminar Nasional Fisika Universitas Riau, 3(1), 2-15.

Saraswati, Y., Indana, S., \& Sudibyo, E. (2021). Science literacy profile of junior high school students based on knowledge, competence, cognitive, and context aspects. IJORER: International Journal of Recent Educational Research, 2(3), 329-341. https://doi.org/10.46245/ijorer.v2i3.118

Septimarmisa, C., Syamsurizal., \& Lufri. (2018). The influence of two stay two stray learning model nuanced by scientific literacy on students' learning competence in SMPN 4 Kerinci. International Journal of Progressive Sciences and Technologies, 8(1), 89-95. http://dx.doi.org/10.52155/ijpsat.v8.1.393

Sukristanto, Utorowati, S., Fathonah, S., \& Israhayu, E. S. (2019). Pengembangan perangkat pembelajaran berbasis kurikulum 2013 bagi guru-guru smp muhammadiyah banyumas. Seminar Nasional Hasil Penelitian dan Pengabdian Pada Masyarakat 4(1), 255-259 
The Development of Two Stay-Two Stray Cooperative Learning Instrument on Respiratory System to Improve Scientific Literacy Skills

Sulisworo, D., \& Suryani, P. 2014. The effect of cooperative learning, motivation and information technology literacy of achievement. International Journal of Learning and Development, 4(2), 58-64. https://doi.org/10.5296/ijld.v4i2.4908

Sundayana, R. (2014). Statistika penelitian pendidikan. Bandung: Alfabeta.

Supardi. (2015). Penilaian autentik pembelajaran afektif, kognitif, dan psikomotor (konsep dan aplikasi). Jakarta: Raja Grafindo Persada

Suprihatiningrum, J. (2012). Srategi pembelajaran. Yogyakarta: A-Ruzz Media

Sutrianto, Rahmawan, N., Hadi, S., \& Fitriono, H. (2016). Panduan gerakan literasi sekolah di sekolah menengah atas. Jakarta: Direktorat Jendral Pendidikan Dasar dan Menengah Kementrian Pendidikan dan Kebudayaan

Trianto. (2012). Mendesain model pembelajaran inovatif-progresif konsep, landasan, dan implementasinya pada kurikulum tingkat satuan pendidikan (KTSP). Jakarta: Kencana.

Trisnawati, D. R., Kuntjoro, S., \& Faizah, U. (2016). Keterlaksanaan rpp dan keterlaksanaan lks berorientasi pendekatan saintifik $(5 \mathrm{~m})$ materi pencemaran lingkungan dan daur ulang limbah kelas x sma wijaya putra surabaya. BioEdu, 5(3), 384-385.

Ulinnuha, S. K., \& Indana, S. (2018). Pengembangan lembar kegiatan siswa berbasis guided discovery pada materi fotosintesis untuk melatih keterampilan berpikir kritis. BioEdu, 7(2), 388-394.

Utomo, K. D., Soegeng, A. Y., Purnamasari, I., \& Amaruddin, H. (2021). Pemecahan masalah kesulitan belajar siswa pada masa pendemi Covid-19. Mimbar PGSD Undiksha. 9(1), 1-9. http://dx.doi.org/10.23887/jjpgsd.v9i1.29923

Wahidmurni. (2020). Rencana pelaksanaan pembelajaran: RPP 1 lembar. UIN Maulana Malik Ibrahim Malang

Wardono. (2013). Peningkatan literasi matematika melalui pembelajaran inovetif berpenilaian programme for international student assessment. Prosiding Seminar Nasional Evaluasi Pendidikan, 1(1), 608-617.

Wiryanti, W. (2017). Pengembangan perangkat pembelajaran biologi berbasis lingkungan dengan setting modified inquiry untuk meningkatkan karakter dan pemahaman konsep siswa SMA. Jurnal Ilmiah: Pendidikan dan Pembelajaran, 1(1), 1-7. http://dx.doi.org/10.23887/jipp.v1i1.11956

Yaumi, M. (2018). Media dan teknologi pembelajaran. Jakarta: Prenadamedia Group.

Zainab, Wati, M., \& Mirian, S. (2017). Pengembangan instrumen kognitif literasi sains pada pokok bahasan tekanan di kelas VIII smp kota banjarmasin. Jurnal Ilmiah Pendidikan Fisika 1(3), 113-125. https://doi.org/10.20527/jipf.v1i3.1014

Zulfadli. (2017). Pengembangan tes berbasis revisi taksonomi bloom pada materi struktur dan fungsi sel untuk siswa kelas xi di sma kota tarakan. Jurnal Pendidikan Biologi Indonesia, 3(2), 174-182. https://doi.org/10.22219/jpbi.v3i2.3973

\footnotetext{
*Sylvani Kumala Ulinnuha (Corresponding Author)

Universitas Negeri Surabaya,

Postgraduate Programme, Science Education Study Program

Continuing Program Development, Jl. Unesa Lidah Wetan, Surabaya, East Java, Indonesia.

Email: sylvani.19009@mhs.unesa.ac.id

Prof. Dr. H. Muslimin Ibrahim, M.Pd

Universitas Negeri Surabaya,

Postgraduate Programme, Science Education Study Program

Continuing Program Development, Jl. Unesa Lidah Wetan, Surabaya, East Java, Indonesia.

Email: musliminibrahim@unesa.ac.id
} 
The Development of Two Stay-Two Stray Cooperative Learning Instrument on Respiratory System to Improve Scientific Literacy Skills

Dr. Utiyah Azizah, M.Pd

Universitas Negeri Surabaya,

Postgraduate Programme, Science Education Study Program

Continuing Program Development, Jl. Unesa Lidah Wetan, Surabaya, East Java, Indonesia.

Email: utiyaazizah@unesa.ac.id 